\title{
A NATIVE PAINTING FROM NYASALAND
}

Captain Hardy, F.R.G.S., writing from Fort Johnston, Nyasaland, sends us a photograph of a wall-painting on a hut in Mponda's village, on the Shire, near the lower end of Lake Nyasa.

The painting (here reproduced) is quite recent, in fact, probably done this year. Unfortunately Captain Hardy does not mention the nationality of the artist. Mponda's people are, properly, Machinga Yaos, but there has been a great mixture of tribes in this part, through Coast men settling here and bringing slaves from a distance, and in other ways.

I have never seen anything of the kind in Nyasaland myself, either near Blantyre or in the Upper Shire District on the other side of the river, but I remember hearing (I think from the Rev. A. Currie) that paintings of animals were very common outside huts on Mount Mlanje. The present inhabitants of Mlanje and the surrounding country are both Yaos and Anyanja, the former being comparatively recent immigrants. Sir Harry Johnston speaks of a tradition current there which may refer to a previous Bushman population, though it is possible that the beings intended are large apes or baboons.

So far, I believe, no paintings of this kind are known to have been produced by any Bantu tribe except under Bushman influence. Some interesting examples of this among the Batlapin, Bahurutse, and Basuto are given in Stow's Native Races of South Africa (p. 495). ${ }^{2}$ I have elsewhere (see Revue des Études Ethnologiques et Sociologiques for March, 1908)

\footnotetext{
${ }^{1}$ See also in South African Folk-lore Jowmal (Vol. II., p. 5I) a note by Mr. C. S. Orpen on some paintings done by "a Mosuto who had been brought up with Bushmen in the Maluti."
} 


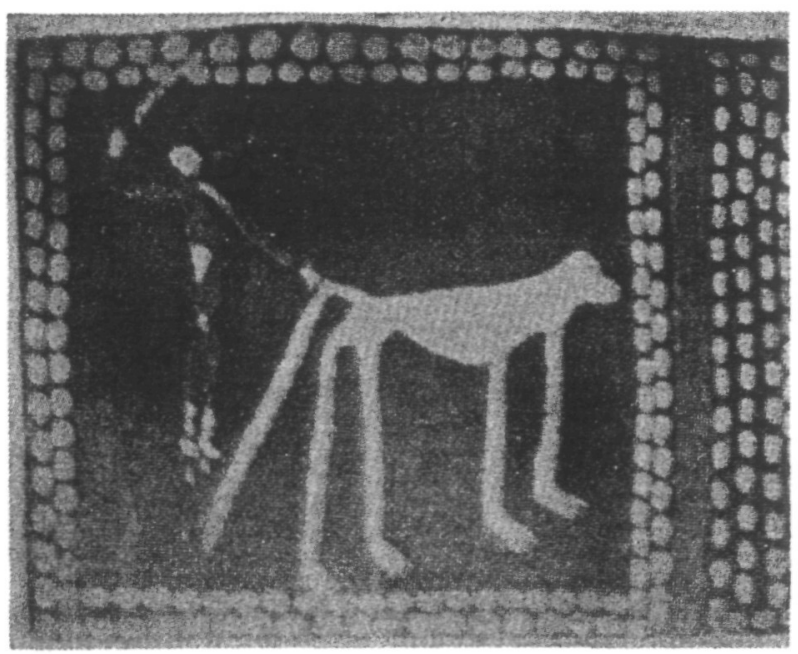

Nativr Painting on a Hut at Mponda's, Nyasaland.

[To face p. 190. 

given reasons for supposing that there is a strong Bushman element in the so-called "Angoni" of the Upper Shire and South Nyasa districts, west of the river. I have not seen so much of the Mlanje people, but certainly some of them exhibit much the same type (small and wiry, in some cases, with tufted hair). Chipoka, whose village is, or was, close to the "Lauderdale" estate, Mlanje, is an example of this type, and, unless my memory misleads me, old Chesinka, now dead, was another. (This Chipoka is a son of the chief who was visited by Messrs. Procter and Scudamore, of the Universities' Mission, in 1862. Chesinka, a contemporary of old Chipoka's, remembered their visit well.) It seems probable that the Anyanja who settled on Mlanje blended with the aboriginal Bushmen in the same way as we may suppose the Anyanja west of the Shire to have done, and as we know to have been the case with the Abatembu in South Africa.

If this supposition is correct, the frescoes on the Mlanje huts may be due to an art handed down from these Bushmen ancestors. It is not surprising that it should no longer be practised by the "Angoni" " west of the Shire, when we remember the disturbed state of the country till within the last ten years. The mountaineers of Mlanje to a great extent escaped the wars and raids of the plain, as is shown by the mere fact of Chipoka's son living very near, if not actually on, the site of his father's village after an interval of thirtytwo years.

The painting photographed by Captain Hardy appears to be somewhat roughly executed, but the delineation of the monkey is very spirited, and, as far as it goes, correct. The man (who appears to be avenging depredations committed on his garden) is portrayed very much in the style of most Bushman paintings. The differences of colouring in the figure would appear to be due to the flaking off of the paint, and not intentional, though it is possible that the artist may have tried to represent the goat-skin fringes (machowa) worn

\footnotetext{
1 These "Angoni" are quite distinct from the real (Zulu) Angoni, having in most cases no other connection with them than the fact of their subjugation by the ruling tribe.
} 
by some "Angoni" at knee and ankle, in imitation of the Zulus.

Dr. Weule, in his recently-published work, Negerleben in Deutsch-Ostafrika, says that "frescoes" of a very rude and elementary character are common on the outside of Yao and Makua huts on the Makonde plateau, north of the Rovuma. They would appear to be quite recent, as the specimen reproduced by Dr. Weule represents a European on horseback, with his caravan. None of these paintings are to be found in the huts of the Makonde, which, indeed, are not plastered, and so have no surface on which they could be placed. (Similarly, the huts in the Upper Shire District, previously mentioned, were not plastered, or only slightly at the beginning of the cold season, the dried mud being removed or allowed to drop off when the hot weather came on.) Perhaps this is because the Makonde, till within the last few years, were continually harassed by the Mavia, from the other side of the Rovuma, for which reason, too, their villages, at least on the southern part of the plateau, are so hidden in the bush that the traveller cannot find the way to them without a guide.

A. WERNER. 